Computed Tomography and Computed Radiography of late Bronze Age Cremation Urns from Denmark

An interdisciplinary attempt to develop methods applied in Bioarchaeological cremation research

Harvig, Lise Lock; Lynnerup, Niels; Amsgaard Ebsen, Jannie

Published in:

Archaeometry

DOI:

10.1111/j.1475-4754.2011.00629.x

Publication date:

2012

Document version

Publisher's PDF, also known as Version of record

Citation for published version (APA):

Harvig, L. L., Lynnerup, N., \& Amsgaard Ebsen, J. (2012). Computed Tomography and Computed Radiography of late Bronze Age Cremation Urns from Denmark: An interdisciplinary attempt to develop methods applied in Bioarchaeological cremation research. Archaeometry, 54(2), 369-387. https://doi.org/10.1111/j.1475-

4754.2011.00629.x 


\title{
COMPUTED TOMOGRAPHY AND COMPUTED RADIOGRAPHY OF LATE BRONZE AGE CREMATION URNS FROM DENMARK: AN INTERDISCIPLINARY ATTEMPT TO DEVELOP METHODS APPLIED IN BIOARCHAEOLOGICAL CREMATION RESEARCH*
}

\author{
L. HARVIG $\dagger$ and N. LYNNERUP \\ Laboratory of Biological Anthropology, Department of Forensic Medicine, Faculty of Health Sciences, University of \\ Copenhagen, Blegdamsvej 3, DK 2200 Copenhagen, Denmark \\ and J. AMSGAARD EBSEN
}

Odense City Museums, Department of Preservation, Overgade 48, DK 5000 Odense C, Denmark

\begin{abstract}
To improve the methods used to study prehistoric cremation rituals, cremation urns from the Danish Late Bronze Age were examined using computed tomography and computed radiography (digital $X$-ray). During micro-excavation, the digital images were used as a registration tool. Our results suggest that osteological ageing and sexing are more accurate when combining CT images with excavated remains. Digital volume rendering further enables a compromised estimation of the original cremation weight. Micro-excavation is clearly a primary cause of bone fragmentation. Cremated remains affected by lower cremation intensity show markedly poorer preservation and recovery than do white calcined fragments. Thus postexcavation estimations of cremation intensity are systematically biased.
\end{abstract}

KEYWORDS: DENMARK, LATE BRONZE AGE, CREMATION URNS, COMPUTED TOMOGRAPHY, COMPUTED RADIOGRAPHY, DIGITAL VOLUME RENDERING, CREMATED BONES, FRAGMENTATION, CREMATION INTENSITY

\section{INTRODUCTION}

Throughout more than a thousand years of Danish prehistory, the practice of cremation was the norm. Thus prehistoric cremation practices far outnumber inhumation practices. Nevertheless, the development of osteological and archaeological research questions related to issues such as cremation rites and ritual practices have not been addressed adequately by osteoarchaeologists, and few relevant interdisciplinary research questions have been put forward.

The practice of cremation existed sporadically throughout the Stone Age and the Early Bronze Age in Denmark. At the onset of the Late Bronze Age, around 1300 BC, the number of cremations increased rapidly, and by $1100 \mathrm{BC}$ cremations outnumbered inhumations. The practice of cremation lasted until around the birth of Christ, when the practice of inhumation was reintroduced (Jensen 2000).

The cremation burials in Bronze Age Scandinavia appear in various forms and contexts. As in other aspects of Nordic Bronze Age culture, the religious customs were heavily influenced by the Urnfield and Lusatian (Lausitz) cultures of central Europe. The reintroduction of cremations in

\footnotetext{
*Received 1 December 2010; accepted 9 June 2011

†Corresponding author: email liseharvig@gmail.com

(C) University of Oxford, 2011
} 
most of Scandinavia and parts of Finland in the Nordic Bronze Age periods II and III should be seen in this context (Kaliff 1997; Harding 2000). In some of the earliest cremation graves, the individual in the grave was placed as in an inhumation grave. The earliest cremations thus resemble the inhumation practice of the Early Bronze Age in style, whereas the later grave types are restricted to single urn graves with urns of clay or organic material. A few graves contain remains of more than one individual, or two urns. Some urns contain metal objects or other artefacts (Jensen 2002, 385). In several cases, the graves also contain animal bones and artefacts, which can be affected by the funeral pyre, as well as other remains of the cremation pyre. The graves are often connected to earlier grave sites or mounds throughout the Late Bronze Age. Various simple constructions of stone and wood, as well as ditches and pits, are seen in connection with the graves and grave sites when preservation allows it. The various constructions comprise cult- or death houses, remnants of cremation pyres and the grave structures themselves. In Sweden and Norway, the less cultivated areas have also revealed examples of urn graves under level ground with constructions on the ground surface; yet these are rarely preserved in Denmark, unless preserved under mounds, forest or moor (Kaliff 1997; Hornstrup 1999; Thrane 2004). In Denmark, the remnants of the grave constructions are primarily found underground, around the urns. In periods IV and V, the graves were often stone-packed urns or urns in stone or wooden cists, when preserved. During the Late Bronze Age, these outer grave constructions slowly disappear, and the urn or cremation pit makes up the grave construction alone. Furthermore, the formerly uniform urn graves now vary more, and various types of cremation pits become common.

A low degree of fragmentation and high variation in stages of combustion of the cremated (human) remains are found in the Late Bronze Age cremations. Thus traditional osteological methods may often be applied with a higher success rate than in other cremation periods (e.g., Hornstrup et al. 2005, 119). Hence the cremations from the Late Bronze Age are obvious study material for a methodological, critical and comparative evaluation of analyses of cremation practices. Nevertheless, in Denmark, cremated remains have usually been studied detached from their original archaeological context; that is, after they have been excavated and cleaned. The aim of studying cremations in a bioarchaeological perspective has often been related to the gathering of basic osteological data and focused on the cremated remains alone. One issue that is frequently discussed within prehistoric cremation research in Scandinavia is the presumed ritual crushing of the cremated remains following the cremation process (Henriksen 1991, 1993; Kaliff 1992, 1997; Sigvallius 1994; Hornstrup 1999; McKinley and Bond 2001). The idea of non-individual graves and pars pro toto burials has also been addressed occasionally (Arcini 2005; Danielsson 2008; Henriksen 2009).

Conventional radiography of prehistoric urns has often been a preferred method when trying to detect and determine the content of the urn before emptying (Becker et al. 2003). Today, radiography is frequently used in most Danish conservation workshops, providing a fast method of identifying objects and determining their location before conservation and excavation of an urn. Computed tomography (CT) has also been recognized as an efficient tool for non-destructive study of archaeological artefacts by scientists dealing with archaeology and cultural heritage (Tout et al. 1980; Lynnerup et al. 1997; Conlogue et al. 2004; Rühli et al. 2004; Ryan and Milner 2006; Lynnerup 2010). One of the first experiments involving prehistoric cremation urns was carried out in the United Kingdom in the early 1990s, when Anderson and colleagues scanned five Roman cremation vessels (Anderson and Fell 1995). Later, CT scans were successfully used on Etruscan cremation urns (Minozzi et al. 2010). Both studies concluded that the method was a valuable, time-saving tool in the excavation, analysis and 
interpretation process of prehistoric urns with a focus on artefacts, and to some degree also on the cremated remains.

Following their ideas, CT and computed radiography (CR) were carried out on six Late Bronze Age urns from Denmark. This is the first systematic interdisciplinary osteoarchaeological study of the process from X-raying and scanning to micro-excavation and analysis of the cremated remains. Our aim is to improve methods used to study ritual practices, religion, life and death in prehistory from cremation burials. Further, we wish to address more critical questions regarding bias caused by preservation factors, excavation, documentation and continuity in an interdisciplinary bioarchaeological context.

\section{MATERIALS}

Due to intensive cultivation of the land from prehistory up to the present day, fully intact urns are rarely found in modern Danish excavations. Of the six urns used in this study, two were from the site Rishøjen (VSM 9048), near Viborg on the Danish Jutland peninsula. These urns were found near the edge of a poorly preserved Bronze Age stone circle (10 $\mathrm{m}$ in diameter), surrounded by settlement structures from various periods of Danish prehistory. The urns were archaeologically dated to the latest Bronze Age and the transition towards the Iron Age, at approximately $500 \mathrm{BC}$. The remaining four urns were from the site Østre Boulevard III (OBM 8441), on the southeastern outskirts of Odense, on the Danish island of Funen. These urns were part of a complex with 19 cremation graves spanning from the Early Bronze Age (around 1300 BC) to the middle Iron Age, approximately AD 500. This site is the second largest ever found on Funen. All of the urns were found in connection with the preserved remains of two early Bronze Age mounds. The four urns analysed here have been dated archaeologically to the first half of the Late Bronze Age, periods IV-V (1100-700 BC). The sites were excavated in 2007 and 2008, respectively (for both locations, see Fig. 1). The urns were taken up within the soil matrix and stabilized, to be emptied under controlled circumstances in a laboratory (see Fig. 2). The dimensions of all of the urns were between 25 and $33 \mathrm{~cm}$ in height, and between 22 and $27 \mathrm{~cm}$ in diameter.

\section{METHODS AND TECHNIQUES}

\section{Computed tomography (CT scanning)}

Unlike radiography, the regions of interest in CT scans are presented without disturbing superimpositions of juxtapositional structures. Instead of producing a single two-dimensional image, the CT scanner generates hundreds or thousands of slices, which may be viewed serially (Hsieh 2002).

CT scanners used in hospitals are equipped with various computer programs allowing rapid image building and three-dimensional visualization, but the software is developed for medical purposes, and thus is tuned to the tissues and organ systems of the living body, so it is easy to pre-program a three-dimensional (3D) rendering of the skeletal tissues in a CT scanner. Archaeological items and cremated remains may require much more work at this stage (see Lynnerup 2008, 106).

Several computer programs allow post-processing of CT data, especially the very important ability to manually edit the single slice images. Currently, we use a program package (MIMICS®, from Materialise $®$, Belgium; www.materialise.be), at the Laboratory of Biological Anthropology in Copenhagen. After importing the CT scanner data file, the single-slice images 


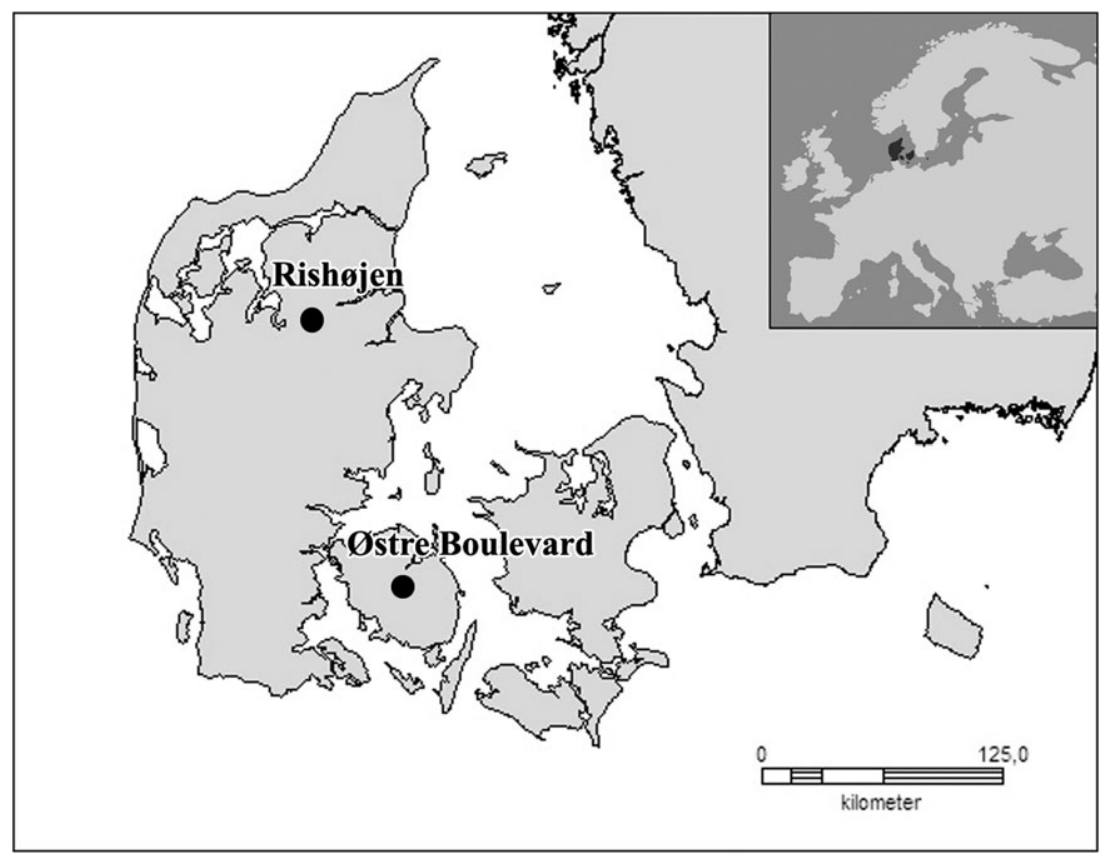

Figure 1 A map of Denmark, showing the sites mentioned in the text; Rish $\phi j e n$, near Viborg, on the Jutland peninsula (VSM 9048); and Østre Boulevard III, near Odense, on the island of Funen (OBM 8441).

are accessible. The program also allows immediate multiplanar reformatting, and the singleimage elements may be edited. To visualize certain structures, a colour-coding is applied 'over' the single greyscale pixels. Different structures—for instance, bone fragments or teeth-may be given specific colours. This involves a process of identifying single structures on the single-slice images and then following these through on the adjacent slices. All the single slices have to be edited, in order to delineate (segment) the single structures. Depending on the object, this is the most time-consuming part of the process, taking approximately $10 \mathrm{~h}$ for each of the three examples shown here (Figs 3, 4 and 8). After the segmentation process, the colour-coded pixels associated with the various structures may then be extracted and used as a basis for 3D rendering. When the segmentation is done, there is some scope for subjectivity. Along with a caveat on slice thickness, this means that the 3D renderings should not be viewed as totally objective and 'true' representations of structures. Once structures or artefacts have been segmented and visualized, they can then be measured and assessed morphologically (see Figs 3 and 4; see also Lynnerup 2008).

The two urns from Jutland were CT scanned free of charge in the Forensic Medical Department of the University of Copenhagen. Likewise, the four urns from Funen were CT scanned free of charge in the Forensic Medical Department of the University of Southern Denmark, in Odense. The protocol and slice thickness of the CT scans of the two urns from Jutland were set to $120 \mathrm{kV}$, $169.5 \mathrm{~mA}$ and $0.5 \mathrm{~mm}$, resulting in 439 and 477 slices, respectively. The scanner type and model used here was a Siemens Somatom Plus 4 Volume Zoom. The protocol and slice thickness of the CT scans of the four urns from Funen was set to $130 \mathrm{kV}$, between 45 and $72 \mathrm{~mA}$ and between 2.5 and $3 \mathrm{~mm}$, resulting in 94, 125, 141 and 145 slices. In this case, the scanner type and model was 


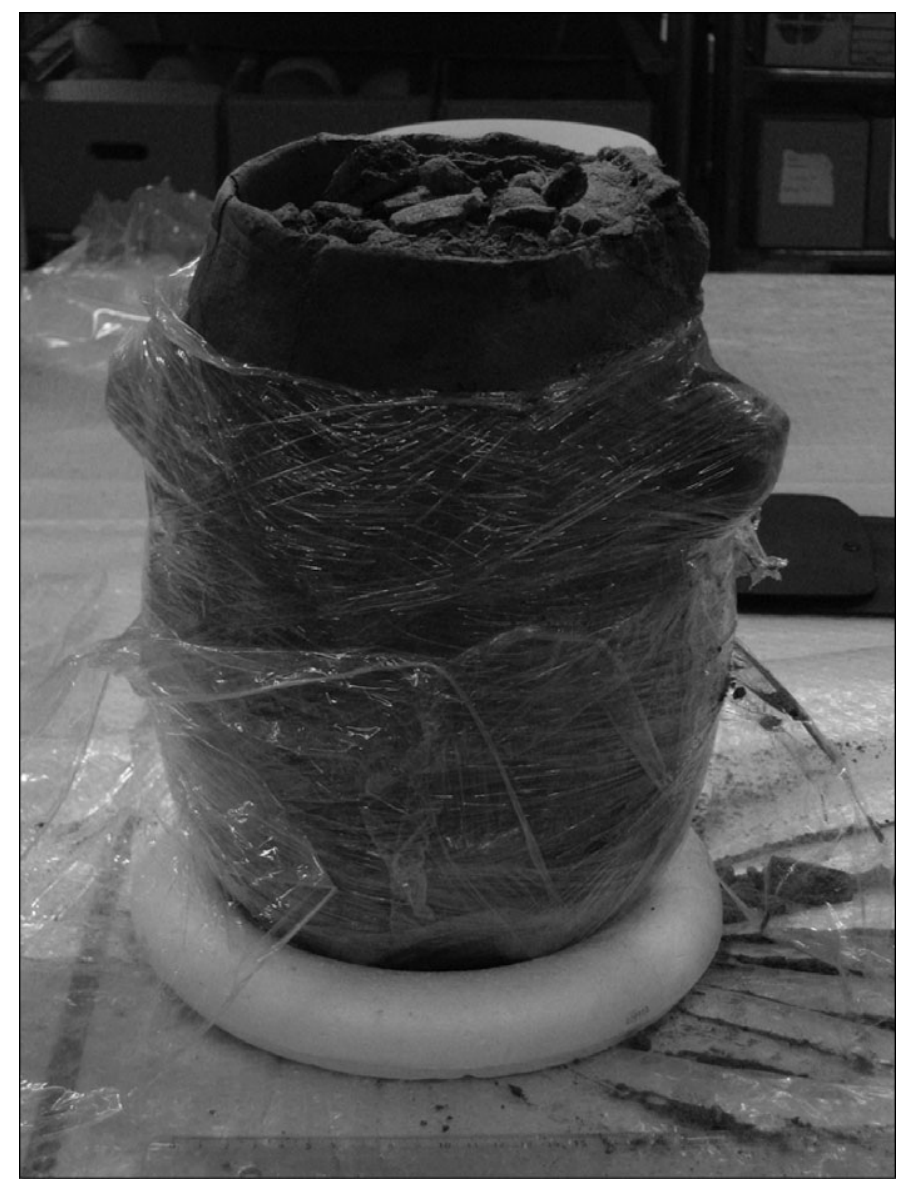

Figure 2 Urn 2 (×159), from Rishøjen, Viborg, Jutland peninsula (VSM 9048), before emptying: height $33 \mathrm{~cm}$.

a Siemens Somatom dual-slice spiral-scanner. In both cases, the protocol and settings were done ad hoc, and the settings used here gave the best images in the above-mentioned cases.

\section{Computed radiography}

Three of the urns from Odense were further analysed using computed radiography (CR) in the Preservation Department of Odense City Museums. In CR, the exposures are carried out using a reusable image plate made of photostimulable phosphor, in contrast to analogue radiography, where a conventional darkroom X-ray film is used. The image plates are, respectively, more sensitive to light and have a better dynamic range, meaning that one exposure can cover a broader range of differing material densities and compositions. The image plates are developed in a special laser scanner that reads and digitizes the X-ray image quickly. The digital X-ray image can following be viewed directly on the computer screen, and enhanced using specialized software with functions such as contrast, brightness, filtration and zoom. The CR was carried out using an X-ray tube (SMART 160E/0.4), a digital scanner (CR XP 50) and image plates (GE IT IPS). 


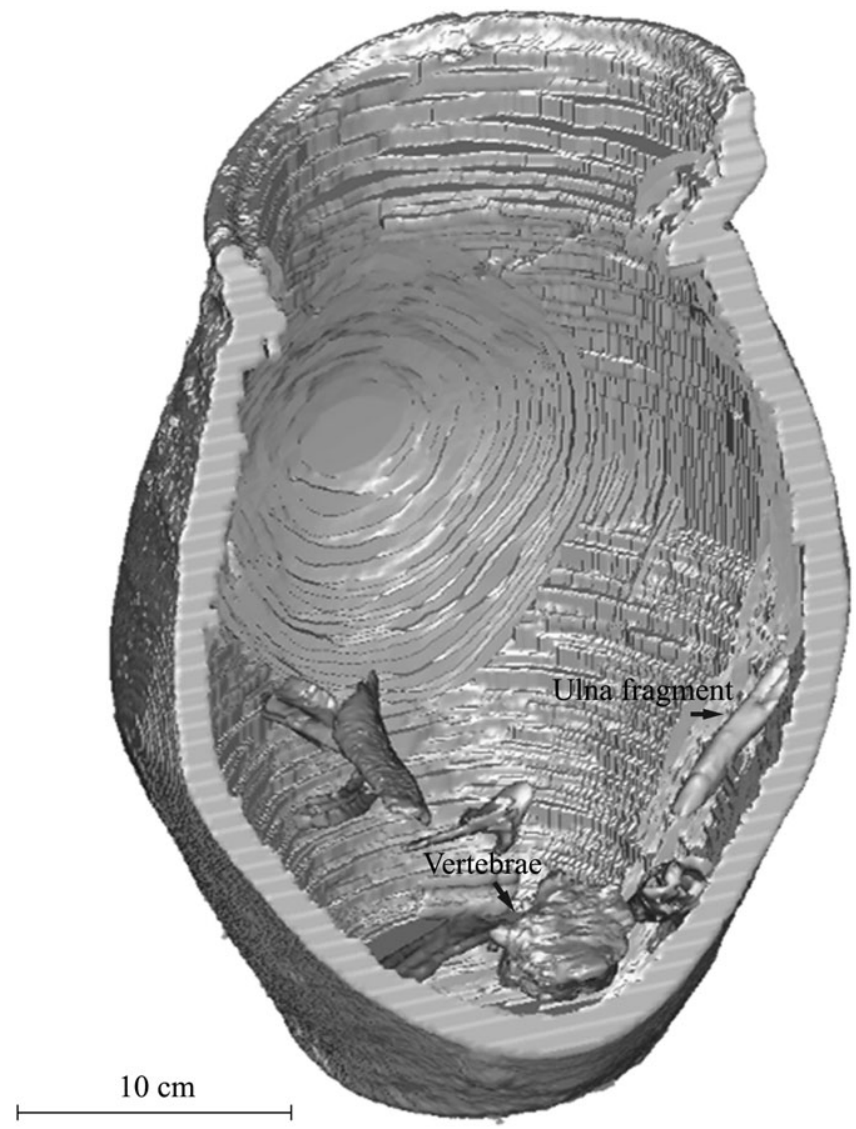

Figure 3 The digitization of selected structures (various long bone fragments, a fragment of an ulna and an almost complete vertebra) in urn 1 (×154), from Rishфjen, Viborg (VSM 9048): height $25 \mathrm{~cm}$.

\section{Micro-excavation}

The two urns from Jutland were emptied in the Laboratory of Biological Anthropology in Copenhagen, whereas the four urns from Funen were emptied in the the Department of Preservation at Odense City Museums. The time taken to empty an urn varied between $4 \mathrm{~h}$ and $9 \mathrm{~h}$.

Five urns were emptied by the first author, using the CT images as guidance, whereas one (urn PS) was emptied by an archaeologist from Odense City Museums, without access to the images. This was done to compare the two situations. In the first five cases, micro-excavation was carried out in horizontal layers from the top downwards. A laptop with all relevant CT data was used during micro-excavation. The layers were followed down in the urn on the digital images simultaneously with emptying the urn. This made it easier to control the excavation strategy. Any relevant observations were registered directly in MIMICS on the relevant slice with a label and an arrow connected to the relevant item. In the sixth case, CT data were not used prior to micro-excavation, and a cross-section of the urn fill was made, which is common when CT images are not available. In this case, it was not possible to get an overview of the 


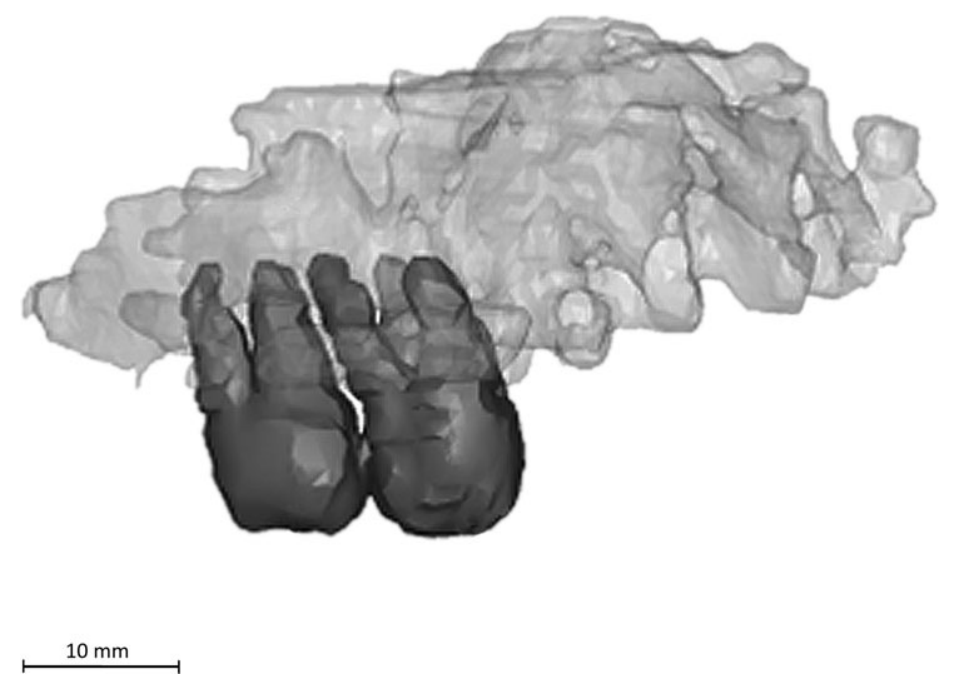

Figure 4 The digitization of two molars in situ in a maxilla fragment from urn 2 (×159): Rishøjen, Viborg (VSM 9048).

entire urn before micro-excavation of the fill, due to the stabilizing material. In all cases, photographs were taken prior to emptying, and the diameter and height of the urn were measured. Tap water was used to moisten the soil. The urns had been stabilized with layers of plaster of Paris in the field and supported using various foam materials during transportation and storage.

\section{RESULTS}

\section{Computed radiography as method}

It was only possible to gain satisfactory images of two of the X-rayed urns, due to the relatively large height of the urns, variations in thickness and covering stones, which caused low image contrast and blurring of the X-ray images. As expected, the results of the X-ray images were good when it came to metal and other possible artefacts in the urns. In particular, a metal needle broken into at least five fragments appeared clearly on the X-ray image, without any post-processing of the image (see Fig. 5).

\section{Computed tomography as method}

As recognized in previous studies, the archaeological benefits of the CT scans of cremation urns are promising (Anderson and Fell 1995; Minozzi et al. 2010). CT scans of the urns prior to emptying proved extremely helpful. It was clearly observable from the scan images whether the urns were tilted. This information was only evident from the scan images, not visible with the naked eye, due to the supporting material and the surrounding soil stabilizing the urns. Measurements could easily be taken with high accuracy using the MIMICS software package (see 'Methods and techniques'). The exact locations of sherds and other artefacts could be marked digitally with find numbers in MIMICS on the scan images. Primary osteoarchaeological results of the CT scans and results related to the aim of our study will be given below. 

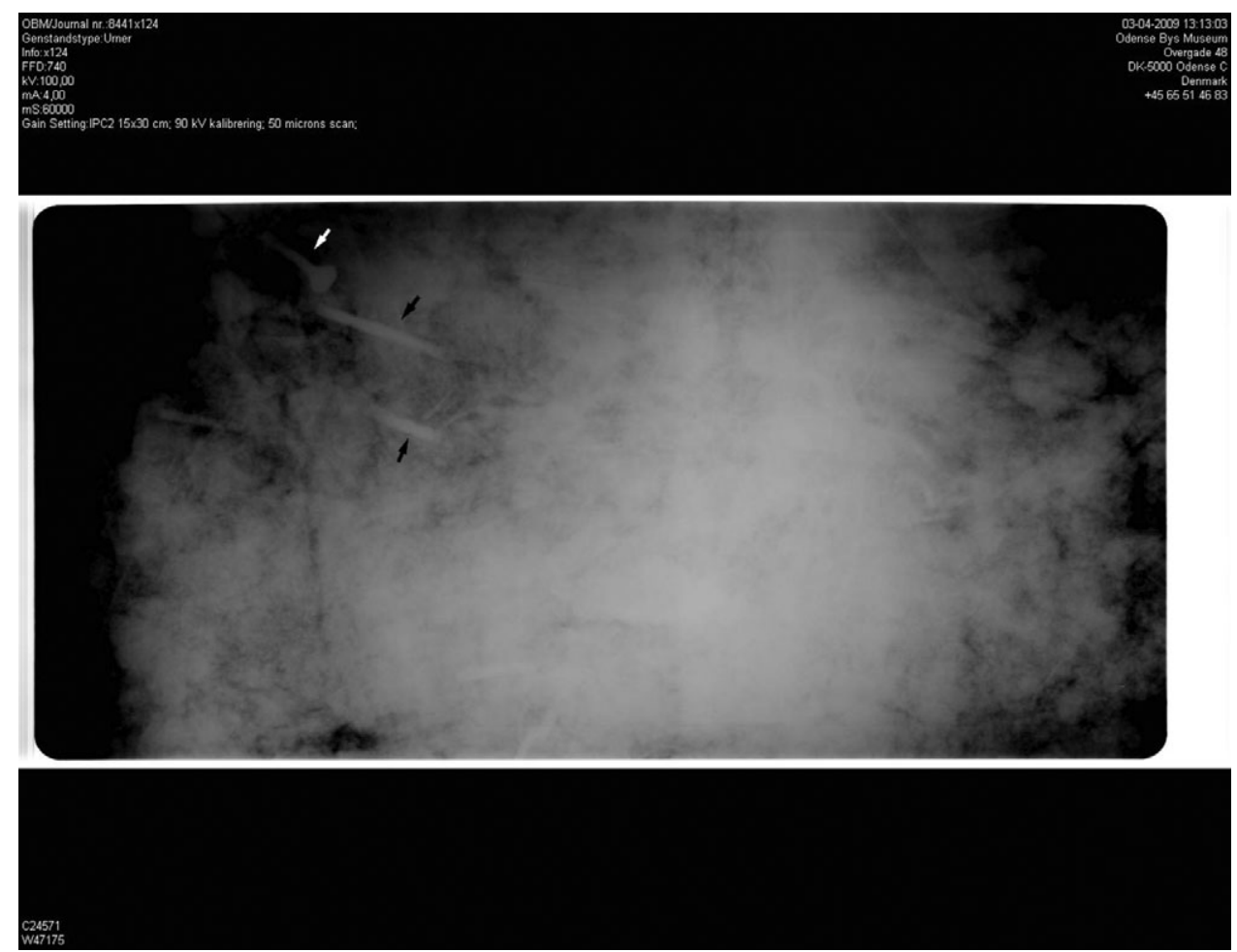

Figure 5 A digital X-ray image of urn PP $(\times 134)$, from $\emptyset$ stre Boulevard III, Funen (OBM 8441): note the broken needle (indicated by the arrows) in the top left corner, clearly visible without any post-processing of the image.

\section{Osteoarchaeological analyses of the urns}

The two urns from Jutland were fairly intact, whereas the four urns from Funen had varying states of compression. In the following, the effect of taphonomy and varying soil pressure on the cremated remains is described, and a short overview of the content of the individual urns is outlined, initially without any post-processing of the images.

Urn $1(\times 154)$ and urn $2(\times 159)$ from Jutland were both intact and unaffected by soil pressure (see Fig. 6). They were found directly under the plough soil and had been surrounded by and filled with fine sand, typical for the Jutland peninsula. Both urns had been isolated from moisture, bearing fairly intact lids. Several structures of cremated bone were immediately present on the CT images. Apart from diaphysal shafts up to $7 \mathrm{~cm}$ in length visible in urn 1 , and $12 \mathrm{~cm}$ in urn 2 (measurable in MIMICS), trabecular structures of vertebrae were visible. Also, parts of the pelvis and an intact distal femur, that had clearly recently fused, were discernible in urn 2. Only a little characteristic transverse curvilinear fracturing was observed. In urn 1, it was obvious that the entire cremated material had settled in the lower third/half of the vessel. In urn 2, a needle had clearly been placed on top of the cremated remains in the top layers of the urn fill.

All four urns from Funen showed various effects of soil pressure. They were all found directly under the plough soil, and had been surrounded by and filled with slightly sandy moist clay with stones. All four urns had damage and/or cracks that exposed the contents to moisture in the 


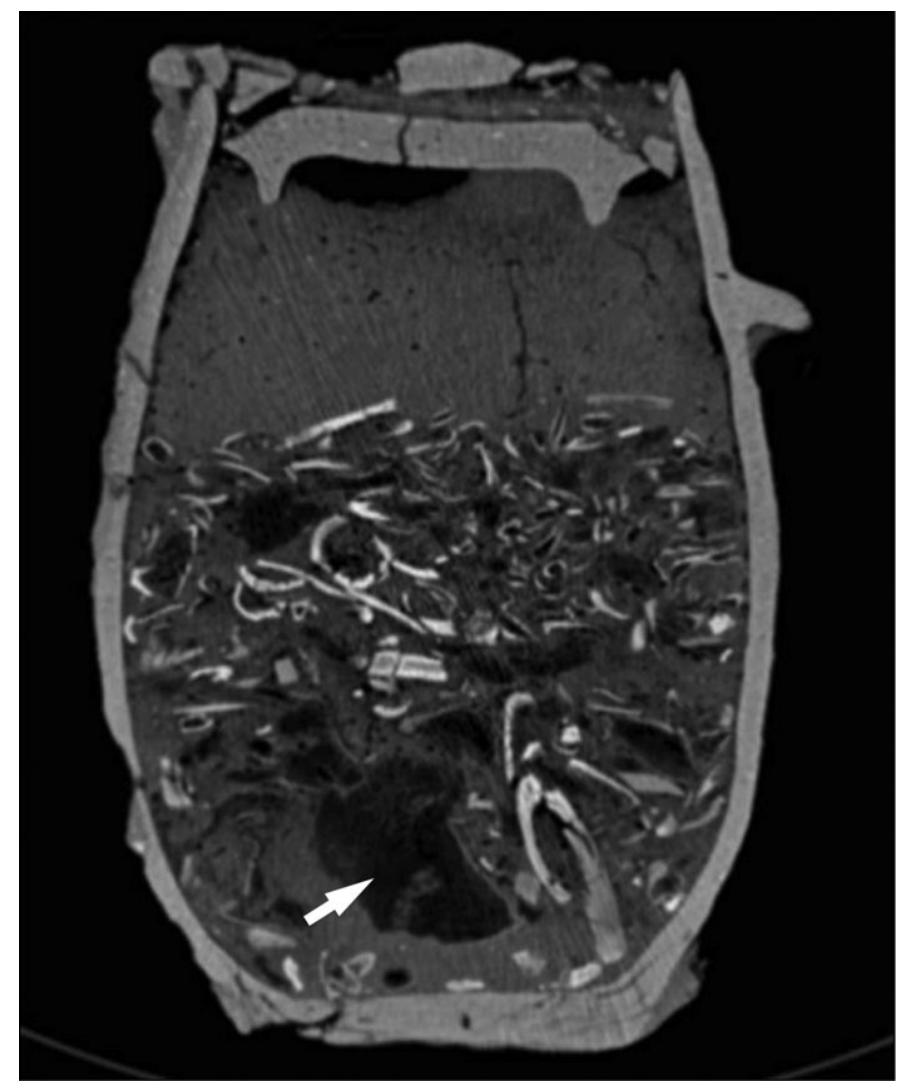

Figure 6 A CT scan of urn $2(\times 159)$, from Rishøjen, Jutland (VSM 9048): height $33 \mathrm{~cm}$. Note the fine sandy fill, the very dense long bone structures and the less dense trabecular structures-amongst others, an oblique cross-section of a pelvic bone (ischium), indicated by the arrow.

surrounding soil. Urn PZ $(\times 138)$ was intact and unaffected by soil pressure. Urn PP $(\times 134)$ showed some deformation at the top northern edge of the vessel, which had collapsed into the urn (see Fig. 7). Urn PT $(\times 120)$ had been under heavy pressure from a cover stone, which had fallen into the urn prior to excavation. The presence of the stone resulted in a blurred scan result, due to the high density of and reflection from the stone. Lastly, urn PS $(\times 124)$ had been under extreme pressure from a stone setting covering the grave construction, causing a total collapse of the entire urn. The CT scan result was, however, very satisfactory, and several structures were immediately present on the CT images. In all urns, the longest preserved fragments were measured digitally to between 8 and $13 \mathrm{~cm}$, without any post-processing of the images. Surprisingly, there was no correspondence between evidence of soil pressure and preserved lengths. Instead, the longest preserved fragments were found in the urns most affected by pressure. It is uncertain at what stage during the 3000 year-long period of soil pressure the urns cracked and/or collapsed.

Characteristic transverse curvilinear fracturing was observed in all of the urns, and in all of the urns it was obvious that the entire cremated material had settled in the lower part of the vessel. This is probably also due to incomplete filling of the urn at the time of burial, which is a common phenomenon in prehistoric urns throughout Europe (see, e.g., Schutkowski and Hummel 1991; 


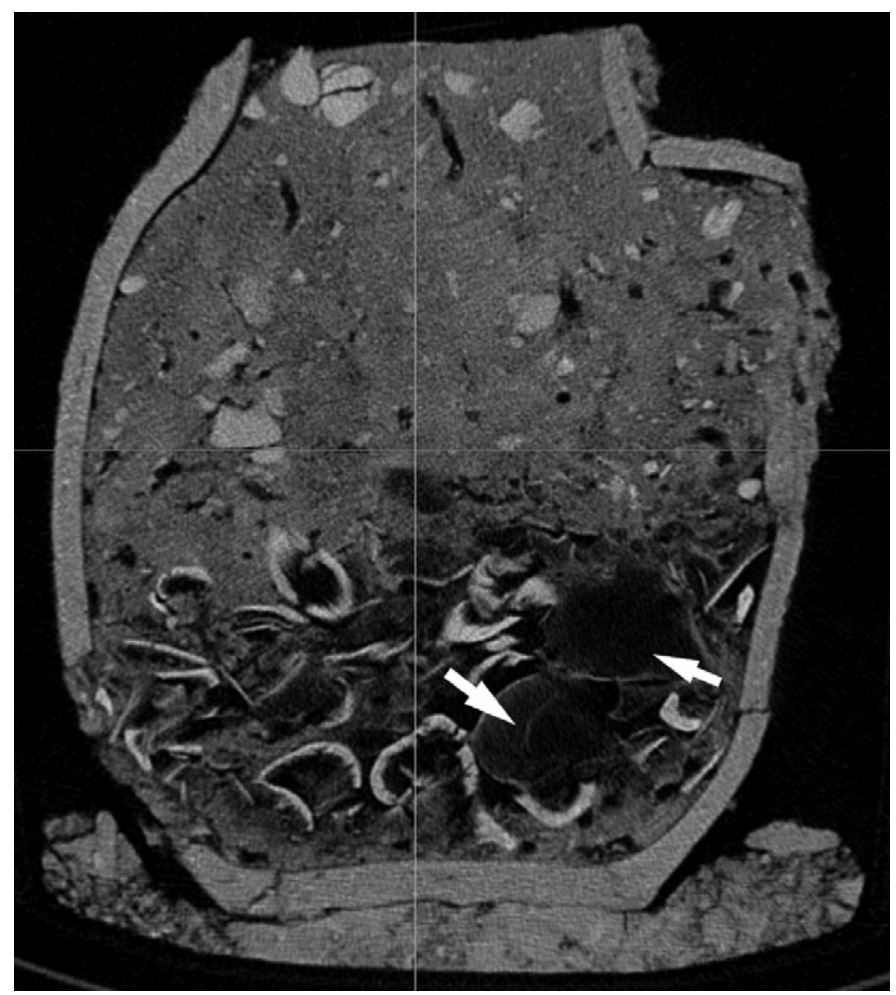

Figure 7 A CT scan of urn PP (×134), from Østre Boulevard III, Funen (OBM 8441): height $27 \mathrm{~cm}$. Again, note the stone, clay, air pockets, long bone structures and trabecular structures (amongst others, a humeral head and a cross-section of a proximal tibia, indicated by the arrows).

Gramsch 2004; Karavanić 2009; Minozzi et al. 2010). In urn PP, trabecular structures of epiphyses-for example, an intact humeral head that had clearly recently fused-were discernible (see Fig. 10 (a) below). In urn PS, trabecular structures of epiphyses-for example, an intact femoral head with a measurable diameter of $41 \mathrm{~mm}$-were clearly present (see Fig. 9 (a) below). Also, parts of one or more metal artefacts were detected in the upper half of the fill.

\section{Virtual anthropology and post-processing of the images}

Anthropological assessments from digital images, so-called virtual anthropology, are becoming widely used in studies of modern and prehistoric human tissue or skeletal material. The analysis of cremated remains from digital images is still in its infancy, but is evolving (Minozzi et al. 2010).

In the urns described in the previous section, several observations could be made from the scan images with the naked eye, without any professional post-processing of the images. First, cremation intensity and bone quality were easy to assess pre-micro-excavation. If the bones were blurred on the images, the quality of the bone was also poor when excavated. Furthermore, colour (although greyscale), warping and dehydration fissures were all visible on the scans (see Figs 6 and 7). Second, the presence of recently fused epiphyses in both urn $2(\times 159)$ from Jutland and 
urn PP $(\times 134)$ from Funen (see Fig. 7$)$ revealed the approximate age of the buried individuals to be around 18-22 years (see Acsádi and Nemeskéri 1970), and must be considered a rather unique result obtained prior to excavation. Also, the intact femoral head and neck in urn PS $(\times 124)$ from Funen and the intact humeral head from urn PP $(\times 134)$, likewise from Funen, revealed that sexing, if possible at all, could be more accurate when using the measurements achievable from CT scans. We do not imply that the digital observations are compatible with macroscopic analyses. Rather, they may often be the only alternative! In many cases, digital observations may be the only achievable analyses of structures that are otherwise damaged during micro-excavation (see Figs 9 (b) and 10 (b) below).

Much can be achieved without any post-processing of the images. However, post-processing may reveal more structures and thereby optimize the immediate assessments made. When the CT images do not yield a satisfactory cross-section of a given structure, it may be relevant to do a 3D rendering of the object to get exact measurements (see Figs 3, 4 and 8). In urn $2(\times 159)$ from Jutland, ageing was further accessible from the digitization of the two intact molars in the maxilla fragment (see Fig. 4), giving a rough estimation of dental wear and indicating male sex from the size (see, e.g., Ditch and Rose 1972; Schwartz and Dean 2005). This estimation was later confirmed by macroscopic analyses.

\section{Volume rendering and estimation of the original cremation weight}

The original volume of the cremated bone material prior to micro-excavation is important, because in this situation the cremated remains are as close as possible to the actual prehistoric situation. Nevertheless, the exact original volume will never be accessible due to factors affecting the volume of air pockets between the bones, such as settling of the cremated remains in the vessel caused by soil pressure, ground shaking and temperature changes-all common phenomena in prehistoric grave urns. Furthermore, bone volume is highly dependent on the size of the bone fragments and the amount of trabecular bone. Therefore digital volume estimations are a solid supplement to post-excavation measurements, facilitating a compromised evaluation of the original bone volume and weight.

For volume estimation, post-processing of the images is required. On the basis of the CT scan, the volume of the cremated remains present in the urn can be reconstructed digitally. In principle, the technique used is the same as the above-mentioned 3D rendering (segmentation) of individual objects. The entire visible skeletal material is digitized, and the total volume is then calculated using MIMICS (see Fig. 8). However, post-processing to this degree involves a substantial amount of work, in that most single slices have to be manually edited (segmented). The estimated total time for segmenting major bones from the surrounding fill, and thus generating a volume estimate, was approximately one week.

To adjust this method and thereby make it comparable to the methods commonly used in laboratories-pouring the cremated remains into a volume-measuring glass- the volume of the inside of the urn up to the top level of the cremated remains may be calculated instead.

Due to a certain correlation between the volume and the weight of cremated remains, volume rendering further enables a calculated estimation of the original weight of the cremated remains before micro-excavation. An estimation can be made on the basis of a correlation between the two parameters (volume and weight) in a given sample-for example, in a certain period, at a certain site or within a certain grave type. The weight of a cremated adult individual can range anywhere from $876 \mathrm{~g}$ (Murad 1998) to $5379 \mathrm{~g}$ (Bass and Jantz 2004), with a 


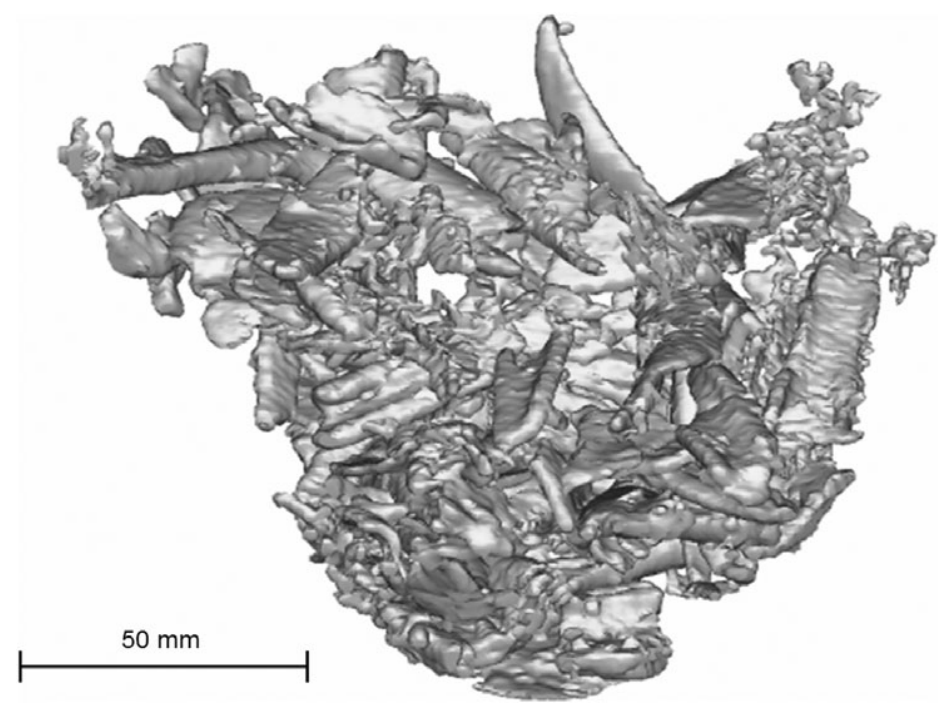

Figure 8 A digital rendering of the visible cremated material from urn 1 ( $\times 154)$, from Rish $\phi j e n$, Jutland (VSM 9048). The volume (exact bone volume without air pockets and other materials) of the 3D-rendered bone material could be assessed as approximately $221 \mathrm{ml}\left(220797.18 \mathrm{~mm}^{3}\right)$. The post-excavation measurement (total content volume with air pockets) was far greater, at approximately $900 \mathrm{ml}$. To adjust this method and thereby make it comparable to the method commonly used in laboratories-pouring the cremated remains into a volume-measuring glass-the volume of the inside of the urn up to the top level of the cremated remains may be calculated instead.

sex difference. For many reasons-for example, the cremation technology and the difficulty in separating cremated bone remains from other remains of the cremation process-experimental results vary. Also, factors such as the age and health of the cremated individual affect the post-cremation weight. Males generally weigh above $1841 \mathrm{~g}$ and females below $4000 \mathrm{~g}$ when all human material from the cremation process has survived (McKinley 1994; Warren and Maples 1997; Grosskopf 2004). In prehistoric contexts, weights are usually lower, depending on the prehistoric ritual, preservation and varying archaeological collecting methods. Nonetheless, there is some variation relating to sex (Niedermann 1988; Wahl 1988; Kunter 1989). Further studies on this subject may provide parameters for maximum and minimum weight estimations in relation to sex and age that are relevant to prehistoric samples. In this case, the proportion of trabecular bone present before and after micro-excavation may give marked variations of volume in relation to weight. While trabecular bone is naturally more voluminous than dense bone, it weighs less. It is often present inside the urn, as seen on our CT scans, but it degrades during micro-excavation (see discussion).

\section{DISCUSSION}

\section{Micro-excavation using CT images}

The CT scans were extremely helpful when carrying out the actual micro-excavation of the urns. It was easy to get an overview of the content of the urn, the extent of stones and the location of possible artefacts or objects. The top fill could be excavated faster than usual. When sherds of the urn broke off, they were kept as such, with a description of their 
approximate location in MIMICS, facilitating later refitting and gluing. These benefits should, nevertheless, be seen in relation to the time and cost involved in the actual scan. In this case, we were able to access the scanners free of charge. Meanwhile, the post-processing and editing process (if needed) exceeds the time used on macroscopic excavation (see 'Methods and techniques').

\section{Fragmentation}

Besides the fragmentation occurring during the cremation process, it also occurs post burial along dehydration lines, due to soil pressure and changes in temperature and moisture in the surrounding soil (McKinley 1994). Also, the actual excavation process causes a further degree of fragmentation, depending on the soil type, excavation methodology, time of excavation and so on.

In the case of the six urns discussed here, the most appropriate approach for a later analysis of the cremated remains was clearly when an osteoarchaeologist assisted micro-excavation and relied on the $\mathrm{CT}$ images. In contrast, information was lost for the one urn that was emptied according to regular standards, especially regarding fragmentation prior to excavation (see 'Methods and techniques').

Despite the presence of several morphological traits and a high percentage of trabecular bone preserved, the cremated remains from the urns were often brittle and in poor condition. The sandy fill in the Jutland urns made recovery fairly easy, whereas the clay fill in the urns from Funen made bone recovery very difficult. Accordingly, when most bone fragments were touched with excavation tools during micro-excavation, they broke into even smaller pieces, despite careful handling (see Figs 9 and 10). This occurred in all four urns from Funen and in at least one of the two urns from Jutland, despite the varying soil texture and preservation conditions. These observations confirm results from earlier studies, which indicate that much fragmentation occurs after insertion in the urn (Gramsch 2007; Minozzi et al. 2010). Trabecular bone was the first to dissolve, as has also been recognized in earlier macroscopic studies (McKinley 1997; Nielsen-Marsch et al. 2000). In several cases, a large fragment could be observed on the CT scan, but touching the fragment with excavation tools made the bones split into several, minor unidentifiable pieces. In other cases, the shape of the fragment remained fairly intact, but the clearly heat-altered and cracked periosteal layer broke off immediately. Lastly, when excavated, long bone both fragmented transversely and shattered longitudinally.

The degree of fragmentation during micro-excavation depends on several factors. Primarily, the texture of the soil surrounding the remains, whether loose sand or dense clay, plays an important role in the survival of morphological traits. Second, our comparison of CT scans and samples examined after micro-excavation revealed that cremation intensity (temperature, oxygen supply and duration) also plays a significant role in the survival of morphological traits. The high degree of fragmentation during the emptying of all the urns studied here was mainly due to the low cremation intensity.

In particular, the non-white, non-mineralized or non-calcined elements were often the first to dissolve and crack during excavation (see also Grosskopf 2004, 112). In fact, they often behave very similarly to the surrounding soil. The poor state of preservation is seemingly related to the fact that a non-complete combustion tends to create a more fragile bone material, with lower mechanical and chemical strength (Stiner et al. 1995, 234). In contrast, completely calcined bone appears to have greater chemical strength, a phenomenon probably caused by the transformation 
(a)

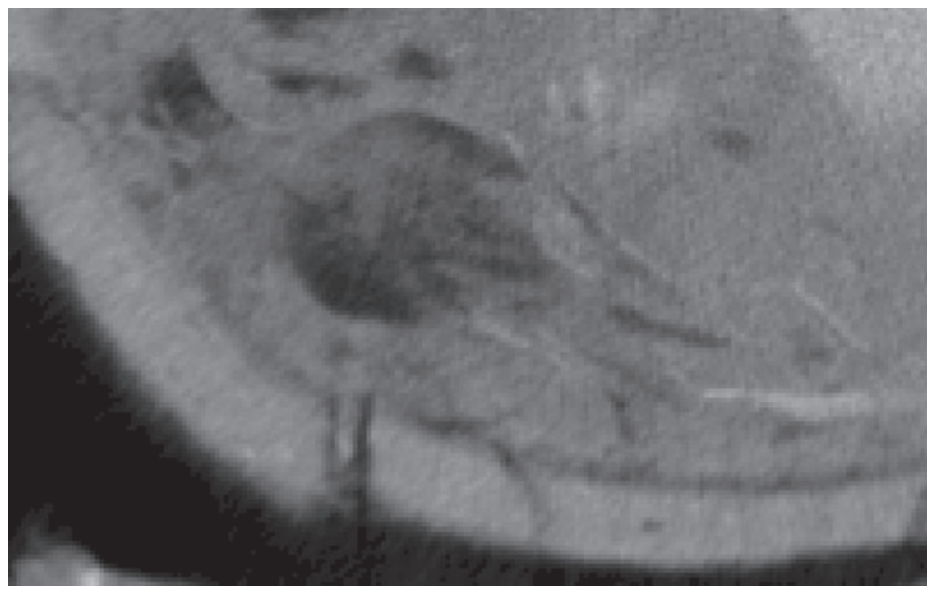

(b)

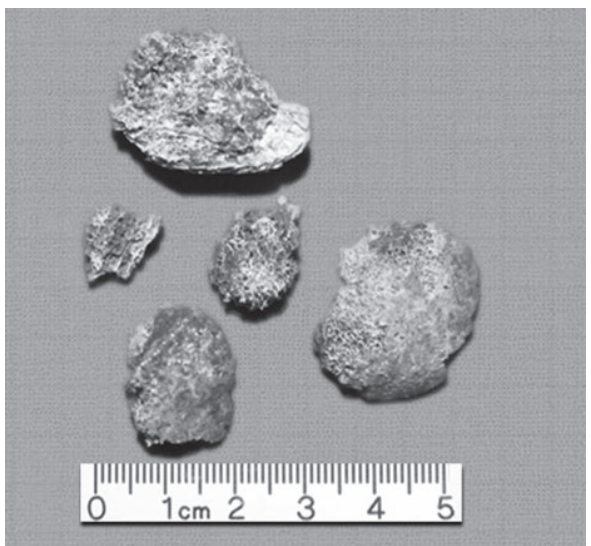

Figure 9 A femoral head (caput femoris) (×438) from urn PT $(\times 120)$ : (a) on the CT scan, diameter 41 mm; (b) after gentle cleaning.

of hydroxyapatite $\left(\mathrm{Ca}_{10}\left(\mathrm{PO}_{4}\right)_{6}(\mathrm{OH})_{2}\right)$ to $\beta$-tricalcium phosphate $\left(\beta-\mathrm{Ca}_{3}\left(\mathrm{PO}_{4}\right)_{2}\right)$, which occurs at temperatures above $800^{\circ} \mathrm{C}$ (Alexandersen et al. 1981, 30; Lange et al. 1987, 18; Gregersen 1991, 3ff.; Borg et al. 1995, 99; Mays 1998, 209). In contrast to the duration of the fire and oxygen supply, temperature is an easily measurable and comparable variable, and therefore the only variable discussed here.

In conclusion, the sample available after micro-excavation contained fewer fragments affected by low cremation intensity than had originally been present (seen on the CT images). Hence, the degree of heat alteration and cremation intensity is not as easily deduced from the sample of post-excavated or cleaned bone fragments as it is during excavation. Therefore, there is not just a tendency towards an extreme overestimation of fragmentation, which has previously been noted by, for example, McKinley (1994). There is also a tendency towards a marked underestimation of the total volume and weight, and-perhaps even more problematic - there is a tendency towards an overestimation of cremation intensity for the cleaned post-excavation samples, resulting in systematically biased estimations of cremation intensity (temperature, oxygen supply and duration). 
(a)
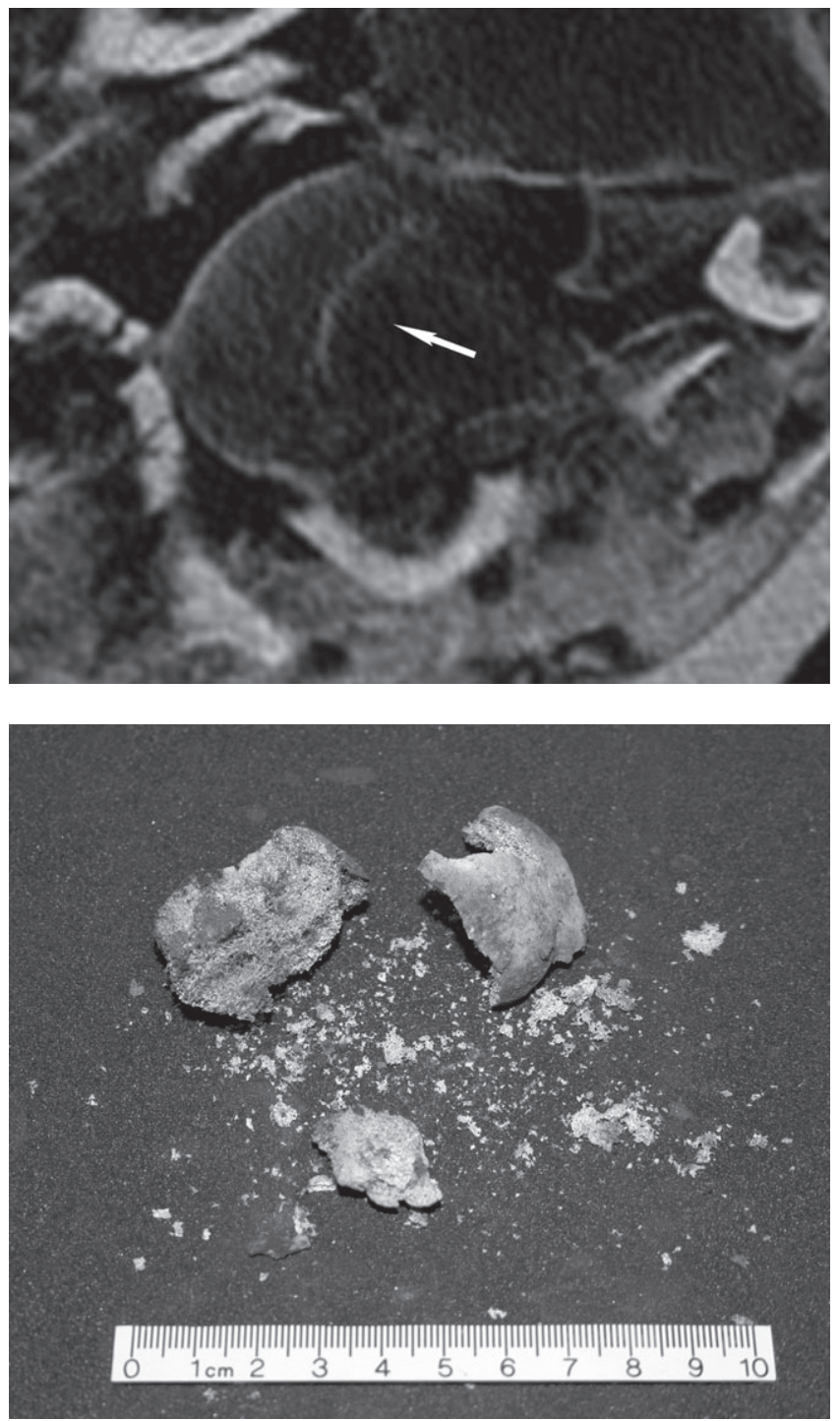

Figure 10 A humeral head (caput humerus) $(\times 463)$ from urn PP $(\times 134)$ : (a) on the CT scan, diameter $39.5 \mathrm{~mm}$; (b) after gentle cleaning.

\section{Ritual aspects}

For the ritual aspects of cremation practice, both fragmentation patterns and placement of the cremated remains in the urn are relevant. The longitudinal splitting of the cremated remains during micro-excavation is crucial to interpretations of, for example, defleshing prior to the cremation process or cremation of either dry or 'green' bone, which is thought to result in these characteristic longitudinal cracks (see, e.g., Whyte 2001, 439). In our opinion, these are more likely to occur arbitrarily during heating of all human bone types when the bone collagen 
contracts and degenerates or simply occur during excavation, cleaning and drying of the bone. Research suggests considerable variation in shrinkage, both transversely and longitudinally, correlated with temperature, the duration of heat exposure and the type of bone (Grosskopf 2004; Fairgrieve 2008).

As mentioned, ritual crushing of the cremated remains before insertion in the urn or grave is a commonly discussed topic in Scandinavia. On the basis of our CT scans, we can, however, dispel this myth. It was apparent that most bone fragments already had several dehydration cracks when lying in situ, which then broke when the urns were emptied. Furthermore, when the fragmentation characteristics are studied thoroughly, it is unmistakably noticeable that the fracture surfaces are fresh and show no evidence of wear, which would otherwise be expected if the bones had already been crushed in prehistory.

In contrast to this possible attempt at a 'deconstruction' of the individual is an indication of a 'reconstruction' of the individual in some European Bronze Age burials (Grosskopf and Gramsch 2004; Sørensen and Rebay 2008). As mentioned earlier, many early cremation burials in Late Bronze Age Scandinavia resemble the former inhumation practice, where the individual is lying in a position resembling the dead body (Madsen 1990; Olsen and Bech 1996). With a few exceptions, throughout the Late Bronze Age in southern Scandinavia and northern Germany, only one individual is buried per grave, whether an urn or various forms of cremation pits (Hornstrup 1999). Certain symbolic expressions in Late Bronze Age Scandinavia also refer to a perception of the grave as a 'house' or a 'home' for the body (Kaliff 1992, 1997; Victor 2002; Svanberg 2005). In other cases, the urns can resemble houses, heads or faces (Kaliff 1992; Aasbøe 2008). Hence, when an urn contains the remains of an entire individual, this could be interpreted as symbolizing a representation or reconstruction of the living body (see, e.g., Gräslund 1994; Grosskopf and Gramsch 2004; Gramsch 2007).

Our CT scans provided the possibility of viewing the content of the urns in situ, and thereby the placement of all individual bone fragments. Previously, this information has only been accessible during excavation. In none of the prehistoric cremation urns CT scanned at the Laboratory of Biological Anthropology in Copenhagen did we find evidence of deliberate placing of the cremated bones in the urns according to any order; for example, anatomical. We therefore have no clear indications of symbolic reconstructions of the anatomical body.

In conclusion, CT scanning is a way of facilitating a contextual discussion. For the osteologist, it enables the possibility of studying bone material in situ - in other words, directly in its context. For the archaeologist, the results may be helpful when studying the rituals of a given period.

\section{CONCLUSIONS AND OSTEOARCHAEOLOGICAL IMPLICATIONS}

We found that computed tomography of urns had several obvious advantages. As recognized earlier by Anderson and Fell (1995) and Minozzi et al. (2010), the shape of the urn, as well as the bone fragments and their location, is preserved and easy to survey in three dimensions. Excavation can be carried out faster and with a far better overview. The texture of the urn fill can be estimated before excavation, and finds can be registered both digitally in situ and manually ex situ. Our results further imply that many detailed osteological observations can be made immediately without any post-processing of the images. Ageing and sexing is more accurate when combining CT images with excavated cremated remains. In addition, the volume of the cremated remains can be reconstructed digitally in situ, when as close to the actual prehistoric situation as possible using different methods. This enables a compromised estimation of a more accurate original weight of the cremated remains. 
Computed radiography has other advantages. It is a fast method for gaining an overview of the material object content of urns, and despite the fact that the metal was recognized using CT, the shape of the objects could be identified more easily on the X-ray images with the naked eye.

The destructive effect on cremated remains from soil pressure before micro-excavation was less than expected. Further, the cremated remains yielded no evidence of any ritual crushing. Instead, micro-excavation was the main cause of destruction. Various morphological traits are lost during micro-excavation. Our results strongly suggest that white calcined fragments survive micro-excavation far better than do less heat-altered fragments. Thus estimations of cremation intensity are systematically biased. Apart from a tendency towards overestimation of the cremation temperature, extreme overestimation of fragmentation could also be avoided.

Long bone both fragmented across the bone and shattered longitudinally when excavated. This information is crucial to the interpretation of, for instance, defleshing prior to the cremation process or cremation of either dry or 'green' bone, which has been thought to result in these characteristic longitudinal cracks. Instead, these probably occur arbitrarily during heating of human bone, when the bone collagen contracts and degenerates.

In contrast to a ritual deconstruction of the dead body by crushing the cremated bones, a symbolic reconstruction of the buried individuals has been discussed. However, in the urns that we scanned, we found no evidence of deliberate placing of the cremated bones in the urns according to any order. Thus, to date, there are no clear indications of a symbolic reconstruction of the body in Denmark, although it has been found in other European Bronze Age cremation contexts.

\section{ACKNOWLEDGEMENTS}

We thank the following persons and institutions for guidance, help and/or financial support: Michael Lundø Jakobsen, Archaeologist, Odense City Museums; Peter Mygind Leth, Deputy Chief Forensic Pathologist, University of Southern Denmark; Mogens Bo Henriksen, Museum Curator, Odense City Museums; and the Danish Council for Independent Research.

\section{REFERENCES}

Aasbøe, M., 2008, Norwegian face-urns: local context and interregional contacts, in The materiality of death: bodies, burials, beliefs (eds. F. Fahlander and T. Østigaard), 105-13, BAR International Series 1768, Oxford.

Acsádi, G., and Nemeskéri, J., 1970, History of human life span and mortality, Akadémiai Kiadó, Budapest.

Alexandersen, V., Bennike, P., Hvass, S., and Stærmose, K., 1981, Egtvedpigen-nye unders $\emptyset$ gelser, Aarb $\phi g e r$ for Nordisk oldkyndighed og Historie, 1981, 17-48, Copenhagen.

Anderson, T., and Fell, C., 1995, Analysis of Roman cremation vessels by computerized tomography, Journal of Archaeological Science, 22, 609-17.

Arcini, K., 2005, Pyre sites before our eyes, in Dealing with the dead: archaeological perspectives on prehistoric Scandinavian burial ritual (eds. T. Artelius and F. Svanberg), National Heritage Board, Ödeshög.

Bass, W. M., and Jantz, R. L., 2004, Cremation weights in east Tennessee, Journal of Forensic Science, 49(5), 901-4.

Becker, M. H., Breuer, H., and Schafberg, R., 2003, Diagnostik an Brandgräbern der römischen Kaiserzeit, Jahresschrift für Mitteldeutsche Vorgeschichte, 86, 133-65.

Borg, G. C., Jonsson, L., Lagerlöf, A., Mattsson, E., Ullén, I., and Werner, G., 1995, Netbrytning av arkeologiskt material i jord-Målsättning och bakgrund, Konserveringstekniska Studier, RIK, 9, 190, Stockholm.

Conlogue, G., Nelson, A. J., and Guillen, S., 2004, The application of radiography to field studies in physical anthropology, Canadian Association of Radiologists Journal, 55(4), 254-7.

Danielsson, I.-M. B., 2008, Bodies and identities in the Scandinavian late Iron Age, in Prehistoric Europe: theory and practice (ed. A. Jones), Wiley-Blackwell, Chichester. 
Ditch, L. E., and Rose, J. C., 1972, A multivariate dental sexing technique, American Journal of Physical Anthropology, 37, 61-4.

Fairgrieve, S. I., 2008. Forensic cremation: recovery and analysis, CRC Press, Boca Raton, FL.

Gramsch, A., 2004, Ritual und Gemeinschaft-Die Darstellung von Altersklassen und Geschlechterdifferenz in der rituellen Kommunikation der Lausitzer Kultur (11.-8. Jhd.) anhand des Gräberfeldes Cottbus Alvensleben-Kaserne (Brandenburg), Dissertation, Universität Leipzig.

Gramsch, A., 2007, A microarchaeological approach to the social significance of Late Bronze Age burial Practices: age and gender at the Lusatian Urnfield of Cottbus Alvensleben-Kaserne (Germany), in Encounters, materialities, confrontations: archaeologies of social space and interaction (eds. P. Cornell and F. Fahlander), 83-99, Cambridge Scholars, Newcastle.

Gräslund, B., 1994, Prehistoric soul beliefs in Northern Europe, Proceedings of the Prehistoric Society, 60, $15-26$.

Gregersen, T., 1991, Brændt materiale-Ligbrænding i fortid og nutid. Identifikation af nedbrudt arkæologisk materiale, Skriftlige indlaeg fra Fuglsфseminar, 1991, 1-9, Dansk Konservator Forbund.

Grosskopf, B., 2004, Leichenbrand_biologisches und kulturhistorisches Quellenmaterial zur Rekonstruktion vor- und frühgeschichtlicher Populationen und ihrer funeralpraktiken, Dissertation, Doktor Philosophiae, Leipzig.

Grosskopf, B., and Gramsch, A., 2004, Leichenbrand-biologische Quelle für Genderforschung, Anthropologischer Anzeiger, 62(3), 281-9.

Harding, A. F., 2000, European societies in the Bronze Age, Cambridge University Press, Cambridge.

Henriksen, M. B., 1991, Et fors $\emptyset$ g med forhistorisk ligbrænding. Nogle kommentarer til unders $\emptyset$ gelsen af brandgrave, Eksperimentel Arkceologi. Studier i teknologi og kultur, 1, 50-60, Lejre.

Henriksen, M. B., 1993, Et ligbrændingsforsøg på Hollufgård—hvad kan det fortælle om jernalderens brandgrave? Fynske Minder, 1993, 99-116, Odense.

Henriksen, M. B., 2009, Brudager Mark—en romertidsgravplads naer Gudme på Sydøstfyn, Fynske Jernaldergrave bd. 6 , Fynske Studier 22, Forlaget Odense Bys Museer, Odense.

Hornstrup, K. M., 1999, Brandgrave fra yngre bronzealder. Muligheder og Perspektiver, KUML, 1999, 99-145, Århus.

Hornstrup, K. M., Glintborg Overgaard, K., Andersen, S., Bennike, P., Hambro Mikkelsen, P., and Malmros, C., 2005, Hellegård—en gravplads fra omkring 500 BC, Aarbøger for Nordisk Oldkyndighed og Historie, 2002, 83-162, Copenhagen.

Hsieh, J., 2002, Computed tomography: principles, design, artifacts, and recent advances, 387, SPIE Optical Engineering Press, Bellingham, WA.

Jensen, J., 2000, The prehistory of Denmark, Routledge, London.

Jensen, J., 2002, Danmarks oldtid. Bronzealder 2.000-500 f.Kr., Copenhagen.

Kaliff, A., 1992, Brandgravskick och föreställningsvärld. En religionsarkeologisk diskussion, Occasional Papers in Archaeology, 4, Uppsala.

Kaliff, A., 1997, Grav och kultplats. Eskatologiska förestallningar under yngre bronsålder och äldre järnålder i Östergötland, Aun, 24, Uppsala.

Karavanić, S., 2009, The Urnfield Culture in continental Croatia, BAR International Series 2036, Archaeopress, Oxford.

Kunter, M., 1989, Leichenbranduntersuchungen in Wederath, in Gräber-Spiegel des Lebens: zum Totenbrauchtum der Kelten und Römer am Beispiel des Treverer-Gräberfeldes Wederath-Belginum (ed. A. Haffner), 415-32, Verlag Philipp von Zabern, Mainz.

Lange, M., Schutkowski, H., Hummel, S., and Herrmann, B., 1987, A bibliography on cremation, PACT, 19, Council of Europe, Strasbourg.

Lynnerup, N., 2008, Computed tomography scanning and three-dimensional visualization of mummies and bog bodies, in Advances in human palaeopathology (eds. R. Pinhasi and S. Mays), 101-20, Wiley, Chichester.

Lynnerup, N., 2010, Medical imaging of mummies and bog bodies, Gerontology, 56(5), 441-8.

Lynnerup, N., Hjalgrim, H., Rindal Nielsen, L., Gregersen, H., and Thuesen, I., 1997, Non-invasive archaeology of skeletal material by CT-scanning and three-dimensional reconstruction, International Journal of Osteoarchaeology, 7, 91-4.

Madsen, O. G., 1990, En høj med kammergrav og andre grave fra bronzealderen, Kuml, 1988-9, 97-118, Viborg.

Mays, S., 1998, The archaeology of human bones, Routledge, London.

McKinley, J. I., 1994, Bone fragment size in British cremation burials and its implications for pyre technology and ritual, Journal of Archaeological Science, 21, 339-42.

McKinley, J. I., 1997, Bronze Age ‘barrows' and funerary rites and rituals of cremation, Proceedings of the Prehistoric Society, 63, 29-145.

McKinley, J. I., and Bond, J. M., 2001, Cremated bone, in Handbook of archaeological sciences (eds. D. R. Brothwell and A. M. Pollard), 281-99, Wiley, New York. 
Minozzi, S., Giuffra, V., Bagnoli, J., Paribeni, E., Giustini, D., Caramella, D., and Fornaciari, G., 2010, An investigation of Etruscan cremations by computed tomography (CT), Antiquity, 84, 195-201.

Murad, T. A., 1998, The growing popularity of cremation versus inhumation: some forensic implications, in Forensic osteology: advances in the identification of human remains (ed. K. J. Reichs), 86-105, Charles C. Thomas, Springfield, IL.

Niedermann, H., 1988, Anthropologische Untersuchung des römischen Brandgräberfeldes Schirenhof (Schwäbisch Gmünd). Dissertation, Albert-Ludwigs-Universität Freiburg im Breisgau.

Nielsen-Marsch, C., Germaey, A., Turner-Walker, G., Hedges, R., Pike, A., and Collins, M., 2000, The chemical degradation of bone, in Human osteology in archaeology and forensic science (eds. M. Cox and S. Mays), 439-54, Greenwich Medical Media, London.

Olsen, A.-L. H., and Bech, J.-H., 1996, Damsgård—en overpløjet høj fra ældre bronzealder per. III med stenkiste og ligbrændingsgrube, Kuml, 1993-4, 155-98, Århus.

Rühli, F. J., Chhem, R. K., and Böni, T., 2004, Diagnostic paleoradiology of mummified tissue: interpretation and pitfalls, Canadian Association of Radiologists Journal, 55(4), 218-27.

Ryan, T. M., and Milner, G. R., 2006, Osteological applications of high-resolution computed tomography: a prehistoric arrow injury, Journal of Archaeological Science, 33, 871-9.

Schutkowski, H., and Hummel, S., 1991, Vorgeschichtliche Bevölkerungen in Schleswig-Holstein. Leichenbranduntersuchungen von Urnenfriedhöfen Mittel- und Ostholsteins in diachronen Vergleich, Offa, 48, 133-262.

Schwartz, G. T., and Dean, M. C., 2005, Sexual dimorphism in modern human permanent teeth, American Journal of Physical Anthropology, 128, 312-17.

Sigvallius, B., 1994, Funeral pyres: Iron Age cremations in North Spånga, Theses and Papers in Osteology, 1, Stockholm University.

Sørensen, M. L. S., and Rebay, K., 2008, From substantial bodies to the substance of bodies: analysis of the transition from inhumation to cremation during the Middle Bronze Age in Europe, in Past bodies: body-centered research in archaeology (eds. J. Robb and D. Boric), Oxbow Books, Oxford.

Stiner, M. C., Weiner, S., and Bar-Yosef, O., 1995, Differential burning, recrystallization, and fragmentation of archaeological bone, Journal of Archaeological Science, 22, 223-37.

Svanberg, F., 2005, House symbolism in aristocratic death rituals of the Bronze Age, in Dealing with the dead: archaeological perspectives on prehistoric Scandinavian burial ritual (eds. T. Artelius and F. Svanberg), National Heritage Board, Ödeshög.

Thrane, H., 2004, Fyns yngre bronzealdergrave, Syddansk Universitetsforlag, Odense.

Tout, R. E., Gilboy, W. B., and Clark, A. J., 1980, The use of computerized X-ray tomography for the non-destructive examination of archaeological objects, Proceedings of the 18th International Symposium on Archaeometry and Archaeological Prospection, Bonn, 14-17 March 1978, 608-16.

Victor, H., 2002, Med graven som granne. Om bronsålderns kulthus, Aun, 30, Stockholm.

Wahl, J., 1988, Süderbrarup. Ein Gräberfeld der römischen Kaiserzeit und Völkerwanderungszeit in Angeln. II. Anthropologische Untersuchungen, Offa bücher, Neue folge, 64, Wachholtz, Neumünster.

Warren, M. W., and Maples, W. R., 1997, The anthropometry of contemporary commercial cremation, Journal of Forensic Science, 42(3), 417-23.

Whyte, T. R., 2001, Distinguishing remains of human cremations from burned animal bones, Journal of Field Archaeology, 28(3/4), 437-48. 